\title{
Keefektifan Model Search, Solve, Create, and Share Ditinjau dari Prestasi, Penalaran Matematis, dan Motivasi Belajar
}

\author{
Rodi Satriawan \\ Program Studi Pendidikan Matematika, Universitas Hamzanwadi Selong. Jalan TGKH Zainuddin \\ Abdul Madjid, No. 132, Lombok Timur, 83611, Indonesia \\ Email: rodysatria@gmail.com \\ Received: 19 January 2016; Revised: 9 May 2017; Accepted: 17 May 2017
}

\begin{abstract}
Abstrak
Tujuan penelitian ini adalah untuk mendeskripsikan keefektifan pembelajaran matematika dengan model search, solve, create, and share (SSCS) dan apakah pembelajaran matematika dengan model SSCS lebih baik dibandingkan dengan model konvensional ditinjau dari prestasi, penalaran matematis, dan motivasi belajar. Penelitian ini merupakan penelitian eksperimen semu dengan desain kontrol grup nonekuivalen. Populasi dalam penelitian adalah seluruh siswa kelas VIII SMP Muhammadiyah Banguntapan yang terdiri dari lima kelas. Sampel penelitian diambil dua kelas secara acak, yaitu kelas VIII-D dan VIIIE. Analisis data yang digunakan adalah uji $T^{2}$ Hotelling's, uji MANCOVA, dan uji lanjut dengan prosedur t-test. Setiap analisis dilakukan pada taraf signifikansi $5 \%$. Hasil penelitian ini adalah pembelajaran matematika dengan model SSCS efektif ditinjau dari prestasi dan motivasi belajar, tetapi tidak efektif ditinjau dari penalaran matematis siswa dan pembelajaran matematika dengan model SSCS lebih baik dibandingkan dengan pembelajaran konvesional ditinjau dari prestasi dan penalaran matematis, tetapi tidak lebih baik ditinjau dari motivasi belajar siswa kelas VIII SMP Muhammadiyah Banguntapan.
\end{abstract}

Kata Kunci: model SSCS, model konvensional, prestasi belajar, penalaran matematis, motivasi belajar siswa

\section{The Effectiveness of the Model of Search, Solve, Create, and Share Terms of Achievement, Mathematical Reasoning, and Motivation to Learn}

\begin{abstract}
The purpose of this study is to describe the effectiveness of teaching with the teaching model search, solve, create, and share (SSCS) and to describe whether teaching by teaching model SSCS better than by model conventional regarding students' achievement, mathematical reasoning, and mathematics learning motivation. This research was quasi-experimental with the non-equivalent control group design. The population was all students of class VIII SMP Muhammadiyah Banguntapan consisting of five classes. The sample taken at random consisted of two classes: classes VIII-D dan VIII-E. Class VIII-D was taught by using the model conventional, while class VIII-E was taught by using the SSCS teaching model. The data were analyzed by using a multivariate test Hotelling's $T^{2}$, MANCOVA test, and tested further by using $t$ test procedures. Each analysis regarding at the significance level of 5\%. The results showed that: the first, the teaching of mathematics by using the SSCS model is effective regarding students' achievement and students' mathematics learning motivation, but it is not effective in terms of mathematical reasoning Banguntapan Muhammadiyah junior high school students of class VIII. The second, the SSCS teaching model is better than the conventional teaching model regarding students' achievement and mathematical reasoning abilities, but not better terms of students' mathematics learning the mathematics of class VIII SMP Muhammadiyah Banguntapan.
\end{abstract}

Keywords: teaching model of SSCS, teaching model of conventional, academic achievement, mathematical reasoning ability, mathematics learning motivation

How to Cite: Satriawan, R. (2017). Keefektifan model search, solve, create, and share ditinjau dari prestasi, penalaran matematis, dan motivasi belajar. Jurnal Riset Pendidikan Matematika, 4(1), 87-99. doi:http://dx.doi.org/10.21831/jrpm.v4i1.7863

Permalink/DOI: http://dx.doi.org/10.21831/jrpm.v4i1.7863 


\section{Jurnal Riset Pendidikan Matematika, 4 (1), 2017 - 88}

Rodi Satriawan

\section{PENDAHULUAN}

Perkembangan ilmu dan pengetahuan yang pesat di abad ke-21 menimbulkan persaingan dari tiap negara untuk menciptakan berbagai inovasi di berbagai bidang dan dimensi kehidupan. Setiap negara melakukan berbagai upaya untuk mengimbangi pesatnya perkembangan ilmu dan teknologi dengan mempersiapkan sumber daya manusia (SDM) yang unggul dan kreatif. SDM yang diperkirakan dapat memenuhi tantangan tersebut adalah mereka yang antara lain memiliki kemampuan berpikir secara kritis, logis, sistematis, dan kreatif sehingga mampu menghadapi berbagai tantangan kehidupan secara mandiri dengan penuh rasa percaya diri (Suryadi, 2012, p. 1).

Matematika sangat erat dengan kehidupan sehari-hari, karena itu matematika sering disebut sebagai aktivitas manusia (human activity). Matematika berkaitan erat dengan kehidupan sehari-hari sehingga siswa akan mampu menerapkan matematika dalam konteks yang berguna bagi siswa, baik dalam dunia kehidupannya ataupun dalam dunia kerjanya kelak (Turmudi, 2009 , p. 3). Selain itu, mempelajari matematika memiliki potensi untuk dapat membiasakan seseorang berpikir kritis, logis, dan dapat meningkatkan daya kreativitasnya.

Dalam kehidupan sehari-hari sering kali siswa dihadapkan dengan berbagai persoalan yang mudah ataupun kompleks yang berhubungan dengan matematika. Oleh karena itu, siswa perlu dibekali dengan pengetahuan yang cukup dalam rangka memecahkan persoalan tersebut. Dalam pembelajaran di sekolah siswa perlu diberikan kesempatan untuk lebih bisa bereksplorasi dan bereksperimen terhadap suatu materi pembelajaran sehingga siswa dapat menyelesaikan persoalan berdasarkan pengetahuan yang dimilikinya.

Pelaksanaan pembelajaran matematika diharapkan menggunakan pendekatan dan strategi pembelajaran yang memicu para siswa agar aktif berperan dalam proses pembelajaran dan membimbing siswa dalam proses pemecahan masalah (problem solving). Pada tahap akhir diharapkan pembelajaran matematika dapat membentuk sikap-sikap positif siswa seperti kedisiplinan, tanggung jawab, toleransi, kerja keras, kejujuran, menghargai perbedaan, dan lain sebagainya. Selanjutnya di kemudian hari dapat terbentuk pola berpikir dan bertindak ilmiah yang merupakan suatu kebiasaan. Untuk mencapai hasil pembelajaran seperti yang diharapkan, guru perlu mengembangkan pendekatan atau model, perencanaan atau pola yang digunakan sebagai pedoman dalam merencanakan pembelajaran sebagai kerangka konseptual yang menguraikan prosedur sistematis dalam mengorganisasi pengalaman belajar untuk mencapai tujuan belajar tertentu dan berfungsi sebagai pedoman bagi para perancang pembelajaran dan para guru dalam merencanakan aktivitas pembelajaran.

Prestasi belajar dalam penelitian ini didefinisikan sebagai hasil pencapaian siswa dari proses belajar yang telah dilakukan sebagai akibat dari penerapan model pembelajaran tertentu yang diukur melalui tes. Prestasi belajar siswa diukur dengan menggunakan tes setelah siswa melakukan proses pembelajaran di kelas. Prestasi belajar tersebut berkaitan erat dengan hasil pencapaian siswa dalam pengerjaan tes (Brown \& McNamara, 2011, p. 16; Linn et al., 2009, p. 9; Muijs \& Reynolds, 2005, p. 232).

Berdasarkan hasil Trends In International Mathematics and Science Study (TIMSS), pencapaian rata-rata peserta Indonesia pada TIMSS 2011 adalah sebesar 386, yang berarti berada pada level rendah (Rosnawati, 2013, p. 2). Pencapaian rata-rata peserta Indonesia pada TIMSS mengalami penurunan dari pencapaian rata-rata pada TIMSS 2007 yaitu sebesar 397, dimana kerangka kerja TIMSS 2011 tidak berbeda dengan kerangka kerja TIMSS 2007. Pada dimensi konten tampak bahwa kemampuan rata-rata peserta didik Indonesia pada tiap dimensi konten berada di bawah rata-rata Internasional. Rata-rata persentase yang paling rendah yang dicapai oleh peserta didik Indonesia adalah dimensi konten aljabar, yaitu ada $22 \%$ peserta didik Indonesia mampu menyelesaikan masalah aljabar. Sementara itu, dalam domain kognitif pencapaian rata-rata peserta didik Indonesia juga masih berada di bawah rata-rata Internasional. Rata-rata persentase yang paling rendah yang dicapai oleh peserta didik Indonesia adalah domain kognitif pada level penalaran (reasoning), yaitu sebesar 17\% (Rosnawati, 2013, p. 2). Berdasarkan data TIMSS 2011 tersebut, dimensi konten aljabar dan domain kognitif pada level penalaran perlu mendapat perhatian yang khusus.

Berdasarkan hasil prasurvei, peneliti memperoleh data berupa nilai rata-rata matematika ujian nasional siswa SMP Muhammadiyah Banguntapan pada tahun pelajaran 2011/2012 dan 2012/2013 yang disajikan dalam Tabel 1. 
Tabel 1. Nilai Rata-rata Matematika Ujian

Nasional Siswa SMP Muhammadiyah Banguntapan

\begin{tabular}{lcc}
\hline Tahun Pelajaran & $\mathbf{2 0 1 1 / 2 0 1 2}$ & $\mathbf{2 0 1 2 / 2 0 1 3}$ \\
\hline Nilai rata-rata sekolah & 4,16 & 3,97 \\
Nilai Rata-rata kabupaten & 6,42 & 6,10 \\
Nilai Rata-rata propinsi & 6,28 & 6,12 \\
\hline & \multicolumn{2}{c}{ Sumber: BNSP }
\end{tabular}

Berdasarkan Tabel 1, nilai rata-rata matematika ujian nasional siswa SMP Muhammadiyah Banguntapan pada tahun pelajaran 2011/ 2012 sebesar 4,16 dan pada tahun pelajaran 2012/2013 sebesar 3,97. Hal ini berarti bahwa terjadi penurunan nilai rata-rata matematika sebesar 0,19 . Selain itu, pencapaian nilai ratarata matematika pada ujian nasional siswa SMP Muhammadiyah Banguntapan tahun pelajaran 2011/2012 dan 2012/2013 masih berada di bawah nilai rata-rata kabupaten dan provinsi.

Selain data berupa nilai rata-rata matematika ujian nasional, peneliti juga memperoleh data berupa daya serap ujian nasional siswa SMP Muhammadiyah Banguntapan pada kemampuan memahami bentuk aljabar, konsep persamaan dan pertidaksamaan linier, persamaan garis, himpunan, relasi, fungsi, sistem persamaan linier, serta penggunaannya dalam pemecahan masalah disajikan pada Tabel 2 .

Tabel 2. Persentase Daya Serap Ujian Nasional

Siswa SMP Muhammadiyah Banguntapan

\begin{tabular}{lcc}
\hline Tahun Pelajaran & $\mathbf{2 0 1 1 / 2 0 1 2}$ & $\mathbf{2 0 1 2 / 2 0 1 3}$ \\
\hline Sekolah (\%) & 35,46 & 37,87 \\
Kabupaten (\%) & 58,81 & 60,58 \\
Propinsi (\%) & 57,77 & 60,84 \\
Nasional (\%) & 76,46 & 59,18 \\
\hline
\end{tabular}

Berdasarkan Tabel 2, daya serap ujian nasional pada tahun pelajaran 2011/2012 sebesar $35,46 \%$ dan pada tahun pelajaran 2012/2013 sebesar $37,87 \%$. Hal ini menunjukkan terjadi peningkatan daya serap pada kemampuan memahami bentuk aljabar, konsep persamaan dan pertidaksamaan linier, persamaan garis, himpunan, relasi, fungsi, sistem persamaan linier, serta penggunaannya dalam pemecahan masalah sebesar $2.46 \%$. Namun, kenaikan daya serap ini masih berada di bawah rata-rata daya serap kabupaten, propinsi, dan nasional, sehingga perlu adanya perbaikan daya serap.

Dalam kegiatan observasi awal, peneliti juga melakukan wawancara dengan guru mata pelajaran matematika kelas VIII SMP Muhammadiyah Banguntapan untuk memperoleh informasi tentang proses pembelajaran di kelas dan keadaan kemampuan siswa. Dari kegiatan wawancara yang telah dilakukan diperoleh beberapa informasi, yaitu: (1) prestasi belajar siswa masih rendah, hal ini dapat kita lihat dari data TIMSS, hasil ujian nasional, dan informasi dari guru; (2) kemampuan penalaran siswa masih terbatas, hal ini dapat kita lihat ketika siswa menyelesaikan soal-soal yang membutuhkan kemampuan penalaran yang baik, sehingga rata-rata ujian yang diperoleh pun rendah; (3) Guru merasa kesulitan untuk menerapkan KKM sebesar 80, karena menurut guru disebabkan oleh kemampuan matematis siswa yang menengah ke bawah; (4) kegiatan pembelajaran matematika masih lebih banyak berpusat pada guru; (5) guru merasa kesulitan melakukan inovasi pembelajaran, karena adanya kendala sarana dan prasarana serta kemampuaan matematis siswa yang rata-rata menengah ke bawah; dan (6) motivasi belajar siswa masih rendah, dalam satu kelas hanya ada 4-5 anak yang benar-benar memiliki keinginan belajar yang kuat.

Belum berkembangnya penalaran matematis diindikasikan sebagai salah satu sebab masalah prestasi belajar siswa. Pentingnya mengembangkan kemampuan penalaran matematis siswa SMP juga diungkapkan oleh NCTM. The National Council of Teachers of Mathematics (2000, p. 262) menyatakan pentingnya penalaran matematis dalam pembelajaran matematika pada siswa kelas menengah. Adapun tujuan dari pembelajaran matematika, yaitu agar siswa dapat: (1) menguji pola dan struktur untuk mendeteksi keteraturan; (2) memformulasikan generalisasi dan konjektur hasil observasi keteraturan; (3) mengevaluasi konjektur; dan (4) mengkonstruksi dan mengevaluasi argumen matematika. Dengan dilaksanakannya pembelajaran yang mengacu pada tujuan tersebut, diharapkan kemampuan penalaran matematis siswa dapat meningkat.

Sejalan dengan NCTM, Ball and Bass (Brodie, 2010, p. 8) juga menyatakan penalaran adalah suatu keterampilan dasar matematika dan diperlukan untuk beberapa tujuan-memahami konsep matematika, menggunakan ide matematik dan prosedur yang fleksibel, dan merekonstruksi pemahaman yang telah dilupakan. Hatano (Brodie, 2010, p. 58) menambahkan bahwa satu bagian penting dari semua kegiatan belajar adalah mencakup bagaimana cara memberi alasan yang bersifat matematis, dimana pengetahuan baru itu selalu terhubung dengan pengetahuan yang ada sekarang, dan bahkan restrukturisasi pengetahuan sekarang terjadi jika 
belajar dengan cara yang benar. Maka, ketika kita mencoba untuk mengembangkan penalaran matematis diantara siswa adalah penting untuk melihat apakah dan bagaimana mereka membuat hubungan tersebut, serta mengubah cara-cara dari proses penalaran yang ada pada mereka. Kemampuan penalaran matematis dalam penelitian ini didefinisikan sebagai kemampuan berpikir yang dimiliki siswa untuk membuat dugaan matematika, membuktikan suatu pernyataan, mengevaluasi kesahihan suatu argumen, dan menemukan pola dari suatu masalah berdasarkan fakta dan sumber yang relevan, sehingga siswa dapat memecahkan masalah tersebut (Copi, 1978, p.5; Brodie, 2010, pp. 7-9; The National Council of Teachers of Mathematics, 2000, p. 262).

Satu variabel yang memiliki peran fundamen dalam menentukan pencapaian belajar dan perkembangan nalar adalah motivasi. Hal ini sesuai dengan apa yang diungkapkan oleh Slavin $(2014$, p. 316) bahwa motivasi adalah salah satu unsur terpenting pengajaran yang efektif. Siswa yang ingin belajar dapat belajar tentang apapun. Tetapi bagaimana cara guru memastikan setiap siswa yang bersedia belajar dan akan mengerahkan upaya yang dibutuhkan untuk belajar, itulah yang rumit.

Brophy (2010, p. 1) juga menyatakan belajar adalah menyenangkan dan menarik, setidaknya ketika kurikulum sangat cocok untuk menarik-ketertarikan dan kemampuan siswa, serta guru menekankan suatu aktivitas. Ketika anda mengajarkan hal yang benar dengan cara yang benar, motivasi akan tumbuh dengan sendirinya. Jika siswa tidak menikmati belajar, ada sesuatu yang salah dengan kurikulum dan pembelajaran anda. Guru harus mendesain pembelajaran yang dapat menyenangkan dan menarik minat belajar siswa, sehingga motivasi siswa akan timbul. Siswa sering tidak memiliki motivasi belajar disebabkan oleh pembelajaran di kelas yang tidak menyenangkan dan menarik. Jadi, inovasi pembelajaran yang menyenangkan dan menarik sangat penting bagi motivasi belajar siswa.

Dalam penelitian ini, motivasi belajar didefinisikan sebagai kecenderungan siswa dalam melakukan kegiatan belajar, baik yang bersifat intrinsik maupun ekstrinsik yang tercermin pada ketekunan, ketertarikan, dan usaha belajar yang di dorong oleh hasrat untuk mencapai prestasi sebaik mungkin (Brophy, 2010, p. 4; Santrock, 2010, p. 438; Schunk, Pintrich, \& Meece, 2008). Rendahnya motivasi belajar siswa terhadap mata pelajaran matematika juga memberikan kontribusi terhadap hasil belajar siswa. Siswa yang kurang termotivasi terhadap mata pelajaran matematika akan menunjukkan sikap kurang peduli, enggan bertanya, suka menganggu siswa lain, senang menyontek, dan kadang-kadang membolos pada saat pelajaran berlangsung. Motivasi belajar juga sangat berperan dalam menentukan keberhasilan siswa dalam belajar. Siswa yang memiliki motivasi belajar tentunya memiliki keinginan untuk mengulangi pelajaran matematika di rumah.

Merespon masalah yang terpapar di atas maka model pembelajaran search, solve, create, and share (SSCS) dinilai memiliki karakter yang sesuai untuk memecahkan masalah pretasi belajar, perkembangan nalar matemaris, dan menumbuhkan motivasi siswa. Model SSCS pertama kali dikembangkan oleh Edward L. Pizzini pada tahun 1985 dalam bidang sains. Menurut Pazzini (1991, p. 3) model SSCS dirancang untuk memperluas dan menerapkan konsep-konsep ilmu pengetahuan dan keterampilan berpikir kritis, serta menggunakan pemecahan masalah model yang holistik.

Menurut Pazzini (1991, p. 5), model SSCS merupakan singkatan dari search, solve, create, dan share. Search: siswa melakukan pencarian pertanyaan melalui penyelidikan tentang topik yang mereka ingin selidiki. Solve: siswa merancang dan melaksanakan penyelidikan untuk memecahkan pertanyaan melalui penelitian mereka. Create: siswa menganalisis dan menginterpretasikan data kemudian membuat hasil analisis data untuk mengkomunikasikan temuan mereka. Share: siswa berbagi hasil mereka dan mengevaluasi penyelidikan mereka.

Model SSCS ini mengajarkan suatu proses pemecahan masalah dan memberikan kesempatan yang cukup bagi siswa untuk melatih dan meningkatkan kemampuan pemecahan masalahnya, sehingga model pembelajaran ini dapat memfasilitasi pengembangan kemampuan berpikir siswa (Pazzini, Abell, \& Shepardson, 1988, p. 23). The National Council of Teachers of Mathematics (2000, p. 256) juga menambahkan bahwa melalui pemecahan masalah, siswa dapat merasakan kekuatan dan kegunaan matematika. Pemecahan masalah adalah pusat untuk penyelidikan dan aplikasi dan harus terjalin dalam seluruh kurikulum matematika untuk menyediakan konteks yang tepat untuk belajar dan menerapkan ide-ide matematika. 


\section{Jurnal Riset Pendidikan Matematika, 4 (1), 2017 - 91}

Rodi Satriawan

Fierro (2013, p. 14) juga menyatakan strategi pemecahan masalah adalah penting karena dua alasan utama. Pertama, strategi pemecahan masalah membantu anda memperkuat dan memperluas pengetahuan anda. Kedua, menjadi alat representasi (seperti membuat tabel atau menggambar diagram) yang akan anda gunakan untuk memahami dan mengajarkan matematika. Hal ini sejalan dengan temuan Ali, Hukamdad, Akhter, \& Khan (2010, p. 70), prestasi siswa yang diajarkan dengan metode pemecahan masalah lebih baik dibandingkan dengan siswa yang diajarkan dengan metode konvensional.

Chen (2013, p. 79) dalam penelitiannya mencoba mengembangkan pembelajaran berbasis masalah (PBL) dengan model SSCS. Berdasarkan hasil penelitiannya itu diperoleh suatu rancangan pembelajaran matematika yang efektif dapat membantu siswa untuk mengintegrasikan dan mengaplikasikan konsep matematika khususnya konsep-konsep geometri yang terkait dengan bagian kerucut. Dari penelitian Chen (2013), maka model SSCS, selain digunakan dalam pembelajaran sains dapat juga digunakan dalam pembelajaran matematika.

Selain penelitian Chen (2013), berdasarkan hasil penelitian Lia \& Bunga (2014, p. 321) yaitu kemampuan berpikir logis siswa yang diajarkan dengan pendekatan pemecahan masalah model SSCS lebih tinggi daripada kemampuan berpikir logis siswa yang diajarkan dengan pembelajaran konvensional. Hasil penelitian Haryanto (2013, p. 85) juga menunjukan peningkatan kemampuan penalaran dan komunikasi matematis siswa yang memperoleh pembelajaran model SSCS dengan pendekatan problem posing lebih baik dari pada siswa yang memperoleh pembelajaran konvensional.

Peneliti ingin melakukan eksperimen dengan memberikan perlakuan berupa pembelajaran dengan model SSCS pada mata pelajaran matematika di SMP Muhammadiyah Banguntapan untuk mengetahui bagaimana keefektifan pembelajaran matematika dengan model SSCS ditinjau dari prestasi, penalaran matematis, dan motivasi belajar. Dengan demikian, tujuan penelitian ini adalah mendeskripsikan keefektifan pembelajaran matematika dengan model SSCS ditinjau dari prestasi, penalaran matematis, dan motivasi belajar, dan juga mendeskripsikan apakah pembelajaran matematika dengan model SSCS lebih baik dibandingkan dengan model konvensional ditinjau dari prestasi, penalaran matematis, dan motivasi belajar siswa kelas VIII SMP Muhammadiyah Banguntapan.

\section{METODE}

Jenis penelitian ini adalah penelitian eksperimen semu (quasi experiment), dengan desain kontrol grup non-ekuivalen (the nonequivalen control group desaign) (Campbell \& Stanley, 1963, p. 47). Penelitian ini dilaksanakan pada semester dua tahun pelajaran 2014/ 2015 dan dilaksanakan berdasarkan jadwal pembelajaran semester genap di sekolah tersebut. Penelitian ini bertempat di SMP Muhammadiyah Banguntapan yang beralamatkan di Wiyoro Lor Baturetno, Kec. Banguntapan Kab. Bantul, D.I. Yogyakarta. Sampel penelitian dipilih secara acak dua kelas dari lima kelas yang ada, sehingga terpilih kelas VIII-E yang terdiri dari 28 siswa sebagai kelas eksperimen dengan model SSCS (kelompok SSCS) dan kelas VIIID yang terdiri dari 28 siswa sebagai kelas kontrol dengan model konvensional (kelompok konvensional).

Sebelum diberikan perlakuan, pada kelompok SSCS dan kelompok konvensional diberikan pretest berupa tes prestasi, tes penalaran matematis, dan angket motivasi dengan tujuan untuk mengetahui kemampuan awal siswa. Setelah diberikan perlakuan kemudian diberikan posttest berupa berupa tes prestasi, tes penalaran matematis, dan angket motivasi belajar dengan tujuan untuk mengetahui keefektifan model pembelajaran yang telah diterapkan ditinjau dari aspek-aspek yang telah ditentukan.

Instrumen yang digunakan dalam penelitian ini terdiri dari instrumen tes dan non-tes. Instrumen prestasi berupa tes berbentuk soal pilihan ganda yang terdiri dari 20 butir soal yang mengukur indikator materi persamaan linear dua variabel. Instrumen penalaran berupa tes berbentuk soal uraian dengan 4 butir soal. Instrumen motivasi belajar berupa angket checklist dengan skala Likert dengan 30 pernyataan. Selain itu, peneliti menggunakan lembar observasi keterlaksanaan pembelajaran untuk mengetahui keterlaksanaan pembelajaran.

Bukti validitas instrumen yang diperlukan dalam penelitian ini adalah validitas isi (content validity) dan validity konstruk (construct validity). Bukti validitas isi terdiri atas face validity dan logical validity. Face validity dilakukan dengan cara meminta pertimbangan minimal dua orang ahli (expert judgment) dan untuk memenuhi logical validity diperlukan tabel kisi-kisi atau indikator terhadap domain 


\section{Jurnal Riset Pendidikan Matematika, 4 (1), 2017 - 92}

Rodi Satriawan

yang diukur. Dalam hal ini, ahli yang dipercayakan sebagai validator adalah dua orang dosen dari program studi pendidikan matematika Universitas Negeri Yogyakarta.

Setelah instrumen memperoleh validasi isi dari para ahli, maka selanjutnya instrumen diuji cobakan. Uji coba instrumen dimaksudkan untuk mengetahui seberapa valid instrumen yang telah di susun. Disamping melakukan bukti validitas instrumen, peneliti juga melakukan estimasi reliabilitas instrumen. Uji coba instrumen penelitian ini diberikan kepada siswa kelas VIII dan kelas IX SMP Muhammadiyah Banguntapan. Pengambilan kelas IX sebagai kelas uji coba instrumen dengan pertimbangan bahwa kelas tersebut telah mempelajari materi persamaan linear dua variabel. Setelah diperoleh hasil uji coba, maka dilakukan analisis faktor (exploratory factor analysis) terhadap hasil uji coba instrumen motivasi belajar. Hal ini dimaksudkan untuk memperoleh bukti validitas konstruk dari instrumen motivasi belajar yang telah disusun.

Analisis faktor dapat dilakukan dengan melihat matriks korelasi secara keseluruhan. Untuk menguji apakah korelasi antar variabel dan dapat tidaknya analisis faktor dilakukan adalah dengan melihat nilai measure of sampling adequacy (MSA). Namun sebelum melihat nilai MSA pada Anti-image matrices terhadap variabel yang akan dibuang atau tidak dibuang dalam analisis faktor terlebih dahulu melihat hasil uji Kaiser-Meyer-Olkin (KMO). Nilai $\mathrm{KMO}>0,5$ berarti analisis faktor dapat dilanjutkan. Selanjutnya apabila $\mathrm{KMO}>0,5$ dan Bartlett's juga signifikan pada 0,5, maka hasil hasil ekstraknya dapat diketahui (eigen value $>1$ menjadi faktor). Analisis dilakukan menggunakan bantuan program SPSS 21.0 for windows.

Berdasarkan hasil analisis faktor tahap kedua terbantuk 8 faktor yang mempunyai nilai eigen value $>1$. Dari faktor tersebut mampu menjelaskan varians motivasi belajar sebesar 4,10\%. Dari item-item dalam faktor tersebut dapat dikatakan bahwa butir-butir pernyataan dalam instrumen motivasi belajar telah memenuhi validitas konstruk. Dari 30 butir pernyataan motivasi belajar terhadap matematika, setelah dianalisis faktor mengelompok menjadi delapan faktor. Dari kedelapan faktor tersebut menyebar sesuai dengan indikator yang ditetapkan sebelumnya. Untuk butir pernyataan yang tidak sesuai antara teoritik dan empirik dimungkinkan adanya faktor ketidakkonsistenan responden dalam memberikan skor angket motivasi belajar yang diberikan.

Reliabilitas menunjuk pada pengertian apakah sebuah instrumen dapat mengukur sesuatu yang diukur secara konsisten dari waktu ke waktu. Dengan kata lain, ukuran yang ditampilkan dalam koefisien reliabilitas merupakan ukuran yang menyatakan keabsahan atau kekonsistenan suatu instrumen. Instrumen yang diestimasi reliabilitasnya, yaitu instrumen yang diujicobakan terlebih dahulu. Estimasi reliabilitas instrumen tes prestasi yang berbentuk pilihan ganda baik pada instrumen pretest maupun posttest menggunakan rumus KR-20. Berdasarkan hasil estimasi diperoleh koefisien reliabilitas instrumen prestasi untuk pretest dan posttest berturut-turut adalah 0,83 dan 0,81 . Karena nilai reliabilitas yang diperoleh lebih dari 0,70 , maka dapat disimpulkan bahwa instrumen prestasi telah memenuhi kriteria reliabel.

Untuk estimasi reliabilitas instrumen penalaran matematis dan angket motivasi belajar digunakan rumus Alpha Cronbach. Berdasarkan hasil estimasi diperoleh koefisien reliabilitas instrumen penalaran matematis untuk pretest dan posttest berturut-turut adalah 0,81 dan 0,75. Dengan demikian, maka dapat disimpulkan bahwa instrumen penalaran matematis telah memenuhi kriteria reliabel, karena nilai reliabilitas yang diperoleh lebih dari 0,70. Untuk instrumen motivasi belajar, berdasarkan hasil estimasi diperoleh koefesien reliabelitas sebesar 0,91. Dengan demikian, maka dapat disimpulkan bahwa instrumen motivasi belajar telah memenuhi kriteria reliabel, karena nilai reliabilitas yang diperoleh lebih dari 0,70 .

Setelah diperoleh koefisien reliabilitas instrumen, dilanjutkan dengan perhitungan SEM untuk masing-masing instrumen. Berdasarkan hasil perhitungan nilai SEM, diperoleh nilai SEM untuk instrumen prestasi pada pretest dan posttest berturut-turut adalah 1,28 dan 1,21. Untuk instrumen penalaran matematis, diperoleh nilai SEM pada pretest dan posttest berturutturut adalah 1,22 dan 1,43. Untuk instrument motivasi belajar, diperoleh nilai SEM pada pretest dan posttest berturut-turut adalah 4,62.

Analisis deskriptif digunakan untuk mendeskripsikan data prestasi, penalaran matematis, dan motivasi belajar yang diperoleh sebelum dan setelah diberikan perlakuan. Kriteria keefektifan model pembelajaran yang digunakan adalah: (1) model pembelajaran dikatakan efektif ditinjau dari prestasi, jika nilai rata-rata klasikal lebih dari 65 dengan rentang nilai antara 0 
sampai dengan 100; (2) model pembelajaran yang digunakan dikatakan efektif ditinjau dari aspek penalaran matematis, jika nilai rata-rata klasikal lebih dari 11 dengan rentang nilai dengan rentang antara 0 sampai dengan 16; dan (3) model pembelajaran yang digunakan dikatakan efektif ditinjau motivasi belajar, jika skor ratarata klasikal lebih dari 103 (dalam kategori tinggi dan sangat tinggi) dengan rentang skor antara 30 sampai dengan 150 .

Analisis statistik inferensial dilakukan dengan perhitungan menggunakan bantuan program SPSS 21.0 for windows. Data yang dianalisis adalah data pretest dan posttest pada aspek prestasi, penalaran matematis, dan motivasi belajar. Analisis dengan menggunakan uji one sample t-test dilakukan untuk mengetahui keefektifan model pembelajaran secara statistik inferensial pada kelompok SSCS dan kelompok konvensional ditinjau dari prestasi, penalaran matematis, dan motivasi belajar. Dalam uji keefektifan model pembelajaran, hipotesis yang diuji memliki kriteria keputusan, yaitu Ho ditolak jika nilai signifikansi kurang dari 0,05 dimana nilai yang dihipotesiskan berdasarkan kriteria yang telah ditetapkan untuk masingmsaing variabel.

Selanjutnya, untuk perbandingan keefektifan dianalsis menggunakan uji Multivariat Analisys of Covariance (MANCOVA) (Rencher, 1998, p. 178) pada taraf siginfikansi 0,05. Sebelum dianalisis data terlebih dahulu dilakukan uji asumsi MANCOVA, yaitu normalitas multivariat, homogenitas multivariat, hubungan linear antara variabel dependen dan kovariat, homogenitas slope, dan perbedaan rata-rata populasi (Rencher, 1998, pp. 178-179). Jika hasil uji perbandiangan keefektifan model pembelajaran menyatakan $\mathrm{H}_{0}$ ditolak, maka akan dilakukan uji lanjut dengan menggunakan uji prosedur $t$-test (Kirk, 2002, p. 730). Uji lanjut dilakukan dengan tujuan untuk mengetahui apakah model SSCS lebih baik dibandingkan model konvensional ditinjau dari masing-masing variabel terikat.

\section{HASIL DAN PEMBAHASAN}

\section{Analisis Deskriptif}

Pada awal tahap pengumpulan data dan sebelum diberikan perlakuan kepada kedua kelompok siswa, peneliti mengumpulkan data sebelum perlakuan dengan melakukan pretest. Sesuai dengan rencana alokasi waktu pengumpulan data di Sekolah yang telah disusun, proses pembelajaran dilakukan sebanyak 8 kali pertemuan (18 jam pelajaran) pada setiap kelompok. Untuk mengetahui keterlaksanaan pembelajaran, peneliti menggunakan instrumen lembar observasi. Berdasarkan hasil pengamatan, keterlaksanaan pembelajaran matematika dengan menggunakan model SSCS mencapai $84,38 \%$ dan pembelajaran matematika dengan model konvensional mencapai $100 \%$.

Berdasarkan hasil analisis deskriptif pada aspek prestasi, nilai rata-rata klasikal prestasi kelompok SSCS pada data pretest $=31,61$ dan pada kelompok konvensional $=26,07$. Dari kedua kelompok siswa, nilai tertinggi prestasi pada data pretest yang dicapai siswa $=50$ dan nilai terendah yang dicapai siswa $=10$. Sementara itu, untuk nilai rata-rata klasikal prestasi kelompok SSCS pada data posttest $=68,57$ dan pada kelompok konvensional $=60,89$. Dari kedua kelompok siswa, nilai tertinggi pada data posttest yang dicapai siswa $=85$ dan nilai terendah yang dicapai siswa $=50$.

Berdasarkan hasil analisis deskriptif pada aspek penalaran matematis, nilai rata-rata klasikal penalaran matematis kelompk SSCS pada data pretest $=1,07$ dan pada kelompok konvensional $=0,36$. Dari kedua kelompok siswa, nilai tertinggi pada pretest yang dicapai siswa $=2$ dan nilai terendah yang dicapai siswa $=0$. Sementara itu, untuk nilai rata-rata penalaran matematis kelompok SSCS pada data posttest pada kelompok SSCS $=9,82$ dan pada kelompok konvensional $=8,43$. Dari kedua kelompok siswa, nilai tertinggi pada data posttest yang dicapai siswa $=12$ dan nilai terendah yang dicapai siswa $=6$.

Berdasarkan hasil analisis deskriptif pada aspek motivasi belajar, skor rata-rata klasikal motivasi belajar kelompok SSCS pada data pretest $=101,54$ dan pada kelompok konvensional $=93,07$. Dari kedua kelompok siswa, nilai tertinggi pada data pretest yang dicapai siswa $=124$ dan nilai terendah yang dicapai siswa $=73$. Sementara itu, untuk skor rata-rata klasikal motivasi belajar kelompok SSCS pada data posttest $=113,18$ dan pada kelompok konvensional $=106,29$. Dari kedua kelompok siswa, skor tertinggi pada data posttest yang dicapai siswa $=135$ dan nilai terendah yang dicapai siswa $=84$.

\section{Hasil Uji Keefektifan Model Pembelajaran}

Dalam uji hipotesis dilakukan uji keefektifan model pembelajaran dan uji perbandingan keefektifan model pembelajaran terhadap data 
posttest. Hasil uji keefektifan pembelajaran dengan model SSCS disajikan pada Tabel 3.

Tabel 3. Hasil Uji Keefektifan Pembelajaran dengan Model SSCS

\begin{tabular}{lccl}
\hline \multicolumn{1}{c}{ Aspek } & $\mathbf{t}_{\text {Hitung }}$ & $\mathbf{t}_{\text {Tabel }}$ & Kesimpulan \\
\hline Prestasi & 2,54 & 2,05 & Efektif \\
Penalaran & $-6,02$ & 2,05 & Tidak efektif \\
Motivasi & 5,80 & 2,05 & Efektif \\
\hline
\end{tabular}

Berdasarkan Tabel 3, pada kelompok

SSCS yaitu pada aspek prestasi diketahui nilai $\mathrm{t}_{\text {hitung }}=2,54>\mathrm{t}_{\text {Tabel }}=2,05$, maka dapat disimpulkan model SSCS efektif ditinjau dari prestasi. Pada aspek penalaran matematis diketahui nilai $\mathrm{t}_{\text {hitung }}=-6,02<\mathrm{t}_{\text {Tabel }}=2,05$, maka dapat disimpulkan model SSCS tidak efektif ditinjau dari penalaran matematis. Pada aspek motivasi belajar diketahui nilai $\mathrm{t}_{\text {hitung }}=5,80>\mathrm{t}_{\text {Tabel }}=2,05$, maka dapat disimpulkan bahwa model SSCS efektif ditinjau dari motivasi belajar.

Hasil uji keefektifan pembelajaran dengan model konvensional disajikan pada Tabel 4.

Tabel 4. Hasil Uji Keefektifan Pembelajaran dengan Model Konvensional

\begin{tabular}{lccl}
\hline \multicolumn{1}{c}{ Aspek } & $\mathbf{t}_{\text {Hitung }}$ & $\mathbf{t}_{\text {Tabel }}$ & Kesimpulan \\
\hline Prestasi & $-3,76$ & 2,05 & Tidak efektif \\
Penalaran & $-10,33$ & 2,05 & Tidak efektif \\
Motivasi & 1,26 & 2,05 & Tidak efektif \\
\hline
\end{tabular}

Berdasarkan Tabel 4, pada kelompok konvensional yaitu pada aspek prestasi diketahui nilai $\mathrm{t}_{\text {hitung }}=-3,38<\mathrm{t}_{\text {Tabel }}=2,05$, maka dapat disimpulkan model konvensional tidak efektif ditinjau dari prestasi. Pada aspek penalaran matematis diketahui nilai $t_{\text {hitung }}=-10,33<\mathrm{t}_{\text {Tabel }}=$ 2,05, maka dapat disimpulkan model konvensional tidak efektif ditinjau dari penalaran matematis. Pada aspek motivasi belajar diketahui nilai $\mathrm{t}_{\text {hitung }}=1,26<\mathrm{t}_{\text {Tabel }}=2,05$, maka dapat disimpulkan model konvensional tidak efektif ditinjau dari motivasi belajar.

Terdapat beberapa faktor yang menyebabkan model SSCS efektif ditinjau prestasi dan motivasi belajar. Dari aspek prestasi, model SSCS efektif karena di dalam proses pembelajaran siswa aktif memecahkan masalah matematika yang ada pada LKS. Hal ini terlihat selama proses pembelajaran di kelas sepanjang pemberian perlakuan diberikan. Berdasarkan lembar observasi keterlaksanaan model pembelajaran selama empat pertemuan, persentase ratarata keterlaksanaan yaitu lebih dari $80 \%$, sehingga dapat disimpulkan bahwa model SSCS terlaksana dengan kategori baik. Dari pengamatan keterlaksanaan model pembelajaran di kelas menunjukkan aktivitas siswa selama proses pembelajaran mendukung siswa dalam mencapai kriteria keefektifan prestasi dan motivasi belajar.

Menurut Pazzini et al. (1988, p. 23), model SSCS mengajarkan proses pemecahan masalah dan memberikan siswa peluang untuk praktik dan memperbaiki keterampilan pemecahan masalah yang mereka miliki. Selain itu, berdasarkan hasil penelitian Ali \& Akhter (2010, p.70) siswa yang diajarkan melalui metode pemecahan masalah lebih baik daripada prestasi siswa yang diajarkan dengan metode tradisional. Terdapat perbedaan yang signifikan antara prestasi siswa matematika diajarkan melalui metode pemecahan masalah dibandingkan dengan metode tradisional.

Selanjutnya ditinjau dari aspek penalaran matematis, diperoleh model SSCS tidak efektif. Sementara, jika kita tinjau dari hasil penelitian oleh Rahmatudin (2013) yaitu peningkatan penalaran matematis siswa yang memperoleh pembelajaran model SSCS lebih baik daripada siswa yang memperoleh model konvensional. Berdasarkan hal ini, maka peneliti perlu mencari tahu faktor apa saja yang menyebabkan model SSCS tidak efektif ditinjau dari penalaran matematis. Setelah dilakukan pengkajian lebih lanjut, diperoleh model SSCS tidak efektif ditinjau dari penalaran matematis karena memang model SSCS tidak cocok untuk diterapkan pada siswa kelas VIII-E SMP Muhammadiyah Banguntapan, khususnya untuk mengembangkan penalaran matematis siswa. Hal ini didukung oleh hasil observasi keterlaksanaan model pembelajaran dikelas, dimana menunjukkan model pembelajaran sudah berjalan dengan baik.

Dalam uji hipotesis, data yang dianalisis adalah data pretest dan posttest. Analisis data pretest bertujuan untuk menguji kesamaan vektor rerata kedua kelompok. Hasil yang diperoleh dari analisis data pretest ini akan menentukan jenis uji statistik yang digunakan dalam menganalisis data yang dikumpulkan setelah diberikan perlakuan. Sebelum melaksanakan uji hipotesis, dilakukan terlebih dahulu uji normalitas dan homogenitas.

Uji normalitas multivariat data pretest dengan menggunakan kriteria $\chi^{2}$, dimana data dikatakan berasal dari populasi berdistribusi normal secara multivariat jika sekitar 50\% data memenuhi $d_{i}^{2}<\chi^{2}$. Berdasarkan hasil uji normalitas multivariat, pada kelompok SSCS diperoleh 13 dari 28 responden atau sekitar 50\% data memenuhi $d_{i}^{2}<2,37$, sehingga. dapat 
disimpulkan bahwa data berasal dari populasi berdistribusi normal secara multivariat. Untuk kelompok konvensional diperoleh 14 dari 28 responden atau sekitar 50\% data memenuhi $d_{i}^{2}<$ 2,37, sehingga dapat disimpulkan dapat disimpulkan bahwa data berasal dari populasi berdistribusi normal secara multivariat.

Uji homogenitas multivariat dilakukan untuk mengetahui varians-kovarians pada populasi apakah sama atau tidak. Hasil uji homogenitas disajikan pada Tabel 5.

Tabel 5. Hasil Uji Homogenitas secara Multivariat pada Data Pretest

\begin{tabular}{ccc}
\hline Box's M & F & Sig. \\
\hline 10,63 & 1,66 & 0,12 \\
\hline
\end{tabular}

Berdasarkan Tabel 5, nilai signifikansi pada data pretest adalah 0,12 , dimana data dikatakan memiliki matrik-kovarians sama (homogen) secara multivariat, jika nilai Box's $M$ Test lebih dari 0,05 (Stevens, 2009, p. 227), sehingga dapat disimpulkan bahwa data matriks varians-kovarians pretest homogen secara multivariat.

Tujuan uji perbedaan kondisi awal terhadap data pretest adalah untuk melihat kemampuan awal siswa pada kedua kelompok sebelum diberikan perlakuan. Hasil perhitungan uji kesamaan vektor rerata kedua kelompok disajikan pada Tabel 6.

Tabel 6. Hasil Uji Kesamaan Vektor Rerata Dua Kelompok

\begin{tabular}{cccc}
\hline Kriteria & Nilai & F & Sig. \\
\hline Hotelling's trace & 0,63 & 10,92 & 0,00 \\
\hline
\end{tabular}

Berdasarkan Tabel 6, nilai signifikansi

Hotelling's Trace adalah 0,00 , dimana $\mathrm{H}_{0}$ ditolak jika nilai nilai signifikansi Hotelling's Trace kurang dari 0,05. Dengan demikian, maka dapat disimpulkan bahwa $\mathrm{H}_{0}$ ditolak yang berarti terdapat perbedaan yang signifikan antara vektor rerata kelompok SSCS dengan vektor rerata kelompok konvensioanal ditinjau dari prestasi, penalaran matematis, dan motivasi belajar. Berdasarkan hasil uji kemampuan awal, maka selanjutnya uji statistik yang akan digunakan untuk menganalisis perbandingan model SSCS dengan model konvensional ditinjau dari prestasi, penalaran matematis, dan motivasi belajar pada data posttest adalah uji MANCOVA.

Sebelum melakukan analisis terhadap data posttest, terlebih duhulu perlu kita menentukan kovariat dengan melakukan uji independent $t$ test terhadap data pretest dan data posttest untuk mengetahui variabel terikat yang mana pada data pretest yang menjadi kovariat. Hasil perhitungan uji independent t-test pada Tabel 7.

Tabel 7. Hasil Uji Independent t-Test untuk Menentukan Kovariat

\begin{tabular}{lcc}
\hline \multicolumn{1}{c}{ Variabel } & T & Sig \\
\hline Prestasi pretest & 2,16 & 0,04 \\
Penalaran matematis pretest & 5,20 & 0,00 \\
Motivasi belajar pretest & 2,91 & 0,00 \\
\hline
\end{tabular}

Berdasarkan Tabel 7, nilai signifikansi dari prestasi, penalaran matematis, dan motivasi belajar pada data pretest berturut-turut, yaitu $0,04,0,00$, dan 0,05 , dimana variabel terikat pada data pretest dikatakan sebagai kovariat jika memiliki nilai signfikansi kurang dari 0,05. Jadi, dapat disimpulkan bahwa prestasi, penalaran matematis, dan motivasi belajar pada data pretest merupakan kovariat dari variabel terikat (dependent) pada data posttest.

Dalam analisis data posttest, peneliti melakukan analisis data dengan menggunakan uji one sample t-test terhadap data posttest untuk mengetahui keefektifan model pembelajaran dan uji MANCOVA (Multivariate Analysis of Covariance) untuk mengetahui perbandingan keefektifan model pembelajaran. Sebelum melakukan analisis terhadap data posttest, terlebih dahulu dilakukan uji asumsi MANCOVA (Rencher, 1998, p. 178). Uji normalitas multivariat data posttest dengan menggunakan kriteria $\chi^{2}$, dimana data dikatakan berasal dari populasi berdistribusi normal secara multivariat jika sekitar $50 \%$ data memenuhi $d_{i}^{2}<\chi^{2}$. Berdasarkan perhitungan uji normalitas multivariat yang telah dilakukan, pada kelompok SSCS diperoleh 15 dari 28 responden atau sekitar 50\% data memenuhi $d_{i}^{2}<2,37$. Dengan demikian, maka dapat disimpulkan bahwa data berasal dari populasi berdistribusi normal secara multivariat. Untuk kelompok konvensional diperoleh 15 dari 28 responden atau sekitar $50 \%$ data memenuhi $d_{i}^{2}<2,37$. Dengan demikian, maka dapat disimpulkan bahwa data berasal dari populasi berdistribusi normal secara multivariat.

Hasil uji normalitas multivariat data posttest dengan menggunakan kriteria $\chi^{2}$, dimana data dikatakan berasal dari populasi berdistribusi normal secara multivariat jika sekitar $50 \%$ nilai $d_{i}^{2}<\chi^{2}$ (Johnson \& Wichern, 1998, p. 182), diperoleh 25 dari 56 responden atau 44,64\% data memenuhi $d_{i}^{2}<3,37$. Dengan demikian, disimpulkan bahwa data berasal dari populasi berdistribusi normal secara multivariat. 
Asumsi MANCOVA yang kedua adalah homogenitas multivariat. Uji homogenitas multivariat dilakukan untuk mengetahui varianskovarians pada populasi apakah sama atau tidak. Pengujian homogenitas secara multivariat dilakukan dengan menggunakan uji Box's M Test. Hasil uji homogenitas multivariat disajikan pada Tabel 8 .

Tabel 8. Hasil Uji Homogenitas secara Multivariat pada Data Posttest

\begin{tabular}{ccc}
\hline Box's M & F & Sig. \\
\hline 7,84 & 1,23 & 0,28 \\
\hline
\end{tabular}

Berdasarkan Tabel 8 , nilai signifikansi pada data posttest adalah 0,12 , dimana data dikatakan memiliki matrik-kovarians sama (homogen) secara multivariat, jika nilai Box's $M$ Test lebih dari 0,05 (Stevens, 2009, p. 227) sehingga dapat disimpulkan bahwa data matriks varians-kovarians untuk data posttest adalah sama atau homogen secara multivariat.

Asumsi MANCOVA yang ketiga adalah hubungan linear antara variabel terikat dan kovariat. Hasil uji hubungan linear antara variabel terikat dan kovariat disajikan pada Tabel 9.

Tabel 9. Hasil Uji Hubungan Linear Antara Variabel Terikat dan Kovariat

\begin{tabular}{cccc}
\hline Kriteria & Nilai & F & Sig. \\
\hline XWilks' lambda & 0,31 & 8,20 & 0,00 \\
\hline
\end{tabular}

Berdasarkan Tabel 9, nilai signifikansi Wilks' Lambda $=0,00$, dimana variabel terikat dan kovariat dikatakan memiliki hubungan linear yang signifikan jika nilai signifikansi Wilks' Lambda kurang dari 0,05. Dengan demikian, maka dapat disimpulkan bahwa terdapat hubungan yang signifikan antara variabel terikat dan kovariat.

Asumsi MANCOVA keempat adalah kesamaan slope regresi tiap kelompok. Hasil uji kesamaan slope regresi masing-masing kelompok disajikan pada Tabel 10.

Tabel 10. Hasil Uji Homogenitas Slope Regresi Masing-masing Kelompok

\begin{tabular}{cccc}
\hline Kriteria & Nilai & F & Sig. \\
\hline$X$ Wilks' Lambda & 0,72 & 1,77 & 0,08 \\
\hline
\end{tabular}

Berdasarkan Tabel 10, nilai signifikansi Wilks' Lambda $=0,08$, dimana slope regresi antara masing-masing kelompok dikatakan sama jika nilai signifikansi Wilks' Lambda lebih dari 0,05 , sehingga dapat disimpulkan bahwa slope regresi antar masing-masing kelompok sama.

\section{Uji Perbandingan Model Pembelajaran}

Hasil uji perbandingan model pembelajaran yang telah dilakukan disajikan pada Tabel 11.

Tabel 11. Hasil Uji Perbandingan Model Pembelajaran

\begin{tabular}{cccc}
\hline Kriteria & Nilai & F & Sig. \\
\hline$X$ Wilks' lambda & 0,74 & 5,81 & 0,00 \\
\hline
\end{tabular}

Berdasarkan Tabel 11, diporelah nilai signifikansi XWilks' lambda adalah 0,00, dimana $\mathrm{H}_{0}$ ditolak jika nilai signifikansi XWilks' Lambda kurang dari 0,05. Dengan demikian, maka dapat disimpulkan bahwa $\mathrm{H}_{0}$ ditolak. $\mathrm{H}_{0}$ ditolak artinya terdapat perbedaan keefektifan antara model SSCS ditinjau prestasi, penalaran matematis, dan motivasi belajar secara keseluruhan. Dengan demikian, maka dilanjutkan dengan melakukan uji lanjut menggunakan prosedur $t$-test.

Analisis uji lanjut terhadap data posttest dilakukan dengan menggunakan prosedur t-test. Analisis uji lanjut dilakukan dengan tujuan untuk mengetahui apakah pembelajaran matematika dengan model SSCS lebih baik dibandingkan model konvensional ditinjau dari masingmasing variabel terikat. Hasil analisis uji lanjut dipaparkan pada Tabel 12.

Tabel 12. Hasil Analisis Uji Lanjut

\begin{tabular}{lcc}
\hline \multicolumn{1}{c}{ Variabel } & $\boldsymbol{t}_{\text {Tabel }}$ & $\boldsymbol{t}_{\text {hitung }}$ \\
\hline Prestasi & 2,00 & 4,46 \\
Penalaran matematis & 2,00 & 3,89 \\
Motivasi belajar & 2,00 & $-0,54$ \\
\hline
\end{tabular}

Berdasarkan Tabel 12, nilai $t_{\text {hitung }}$ pada masing-masing variabel, yaitu prestasi, penalaran matematis, dan motivasi belajar berturut-turut adalah 4,461; 3,889; dan -0,535. Jika ditinjau dari kriteria pengujian yang digunakan, karena nilai $\left|t_{\text {hitung }}\right|$ aspek prestasi belajar dan penalaran matematis lebih dari $t_{\text {Tabel }}$, maka dapat disimpulkan hipotesis nol ditolak. Untuk aspek motivasi belajar, diperoleh bahwa nilai $\left|t_{\text {hitung }}\right|$ kurang dari $t_{\text {Tabel }}$, maka dapat disimpulkan hipotesis nol diterima (Kirk, 2002, p. 730). Dengan demikian maka pembelajaran matematika dengan model SSCS lebih baik dibandingkan dengan model konvensional ditinjau dari prestasi dan penalaran dan tidak lebih baik dibandingkan dengan model konvensional ditinjau dari motivasi belajar.

Pembelajaran matematika dengan model SSCS lebih baik dibandingkan dengan model konvensional ditinjau dari prestasi disebabkan oleh model SSCS pada pelaksanaannya di kelas memberikan kesempatan kepada siswa untuk 
mengembangkan sendiri keterampilan pemecahan masalah yang dimilikinya, sehingga menghasilkan prestasi siswa yang baik. Hal ini sejalan dengan apa yang diungkapkan oleh Pazzini et al. (1988, p. 23) bahwa model SSCS mengajarkan proses pemecahan masalah dan memberikan siswa peluang untuk praktik dan memperbaiki keterampilan pemecahan masalah yang mereka miliki. Keterampilan pemecahan masalah siswa yang baik akan mendukung tingginya prestasi yang diraih oleh siswa.

Selanjutnya, model SSCS lebih baik dibandingkan dengan model konvensional ditinjau dari penalaran matematis. Berdasarkan rencana pelaksanaan pembelajaran (RPP) yang telas disusun dan pelaksanaan pembelajaran yang telah dilaksanakan di kelas, dalam pembelajaran dengan model SSCS siswa mengalami dua fase pembelajaran yang dapat mengembangkan penalaran matematis, yaitu fase search dan fase solve. Pada fase search, siswa mencermati dan menyelidiki masalah yang ada pada lembar kerja siswa (LKS). Kemudian siswa berusaha memahami masalah dengan mencermati dan menyelidiki masalah. Dari memahami masalah, siswa akan memperoleh ide mengenai pemecahan masalah. Fase search termuat dalam langkahlangkah pembelajaran saintifik yang prosesnya berbasis masalah (Wijayanti, 2016, p. 32). Menurut Pazzini et al. (1988, p. 23) bahwa karakteristik lain yang membuat fase search berbeda adalah tujuan dari kelas yang umum, bukan tugas spesifik. Melalui proses tersebut penalaran matematis terlatih dengan baik.

Pada fase solve, siswa memecahkan masalah dengan melaksanakan ide pemecahan masalah yang telah diperoleh pada fase search. Siswa juga mengembangkan keterampilan berpikir kritis seperti kemampuan untuk memilih apa yang seharusnya dilakukan, bagaimana melakukan yang terbaik, data apa yang penting, pengukuran akurat harus bagaimana, dan mengapa setiap langkah diperlukan untuk memecahkan masalah, sehingga pada akhir fase solve siswa menemukan solusi masalah. Proses tersebut melatih siswa dalam bernalar. Menurut Pazzini et al. (1988, p. 23) bahwa fase solve mengakibatkan kognitif siswa berkembang dari merancang dan melaksanakan ide hasil investigasi, yaitu siswa dapat menggunakan salah satu pendekatan deskriptif, korelatif, atau pendekatan penelitian eksperimen.

Hasil penelitian sejalan dengan hasil penelitian oleh Rahmatudin (2013) bahwa peningkatan penalaran matematis siswa yang memperoleh pembelajaran model SSCS lebih baik dari pada siswa yang memperoleh model konvensional. Hasil penelitian Irwan (2001) menunjukkan peningkatan penalaran matematis mahasiswa yang mendapat pendekatan problem posing model SSCS lebih tinggi daripada mahasiswa yang mendapat model konvensional.

Berdasarkan hasil observasi keterlaksanaan pembelajaran di kelas, pembelajaran dengan model SSCS telah berjalan dengan baik. Namun, ternyata diperoleh bahwa model SSCS tidak lebih baik dibandingkan dengan model konvensional ditinjau dari motivasi belajar. Dengan demikian, karena model SSCS sudah terlaksana dengan baik, maka model SSCS tidak lebih baik dibandingkan dengan model konvensional ditinjau dari motivasi belajar, karena memang model SSCS tidak cocok untuk diterapkan pada siswa kelas VIII-E SMP Muhammadiyah Banguntapan, khususnya untuk meningkatkan motivasi belajar.

\section{SIMPULAN}

Hasil penelitian menunjukkan pada taraf signifikan $5 \%$ dapat disimpulkan bahwa pembelajaran matematika dengan model SSCS efektif ditinjau dari prestasi dan motivasi belajar matematika siswa, tetapi tidak efektif ditinjau dari penalaran matematis siswa SMP Muhammadiyah Banguntapan kelas VIII. Selain itu, pembelajaran matematika dengan model SSCS lebih baik dibandingkan dengan pembelajaran konvesional ditinjau dari prestasi dan penalaran matematis, tetapi tidak lebih baik ditinjau dari motivasi belajar matematika siswa SMP Muhammadiyah Banguntapan kelas VIII.

\section{DAFTAR PUSTAKA}

Ali, R., Hukamdad, D., Akhter, A., \& Khan, A. (2010). Effect of using problem solving method in teaching mathematics on the achievement of mathematics students. Asian Social Science, 6(2), 67. http://doi.org/10.5539/ass.v6n2p67

BNSP. (2012). Laporan Hasil Ujian Nasional SMP/MTS Tahun Pelajaran 2011/2012. [Versi Elektronik].

BNSP. (2013). Laporan Hasil Ujian Nasional SMP/MTS Tahun Pelajaran 2012/2013. [Versi Elektronik].

Brodie, K. (2010). Teaching mathematical reasoning in secondary school classrooms. (K. Brodie, Ed.). Boston, MA: Springer US. 
http://doi.org/10.1007/978-0-387-09742-8

Brophy, J. E. (2010). Motivating students to learn (3rd Edition). New York: Routledge.

Brown, T., \& McNamara, O. (2011). Becoming a mathematics teacher. Dordrecht: Springer Netherlands. http://doi.org/10.1007/978-94-007-0554-8

Campbell, D. T., \& Stanley, J. C. (1963). Experimental and quasi-experiment al designs for research. Bosston, MA: Houghton Mifflin Company. Retrieved from

https://www.sfu.ca/ palys/Campbell\&Sta nley-1959-

Exptl\&QuasiExptlDesignsForResearch.pd $\mathrm{f}$

Chen, W.-H. (2013). Applying problem-based learning model and creative design to conic-sections teaching. International Journal of Education and Information Technologies, 7(3), 73-80. Retrieved from

http://www.naun.org/main/NAUN/educati oninformation/c012008-099.pdf

Fierro, R. D. (2013). Mathematics for elementary school teachers. Belmont: Brooks/Cole.

Haryanto, D. (2013). Penerapan model search, solve, create, and share dengan pendekatan problem posing untuk meningkatkan kemampuan penalaran dan komunikasi matematis siswa SMP. Universitas Pendidikan Indonesia. Retrieved from http://repository.upi.edu/1864/

Irwan. (2001). Pengaruh pendekatan problem posing model search, solve, create and share (SSCS) dalam upaya meningkatkan kemampuan penalaran matematis mahasiswa matematika (suatu kajian eksperimen pada jurusan matematika FMIPA Universitas Negeri Padang (UNP). Jurnal Penelitian Pendidikan, 11(1). Retrieved from http://jurnal.upi.edu/penelitianpendidikan/view/1817/pengaruhpendekatan-problem-posing-modelsearch,-solve,-create-and-share--sscs-dalam-upaya-meningkatkan-kemampuanpenalaran-matematis-mahasiswamatematika--suatu-kajian-eksperimenpada-jurusan-matemat
Johnson, R. A., \& Wichern, D. W. (1998). Applied Multivariate Statistical Analysis. Pearson Education International, 226235. http://doi.org/10.1198/tech.2005.s319

Kirk, R. E. (2002). Experimental design: Procedures for the behavioral sciences. Waco, Texas: SAGE Publications, Inc. Retrieved from https://uk.sagepub.com/engb/asi/experimental-design/book233742

Lia, K., \& Bunga, F. (2014). Problem solving learning approach using search, solve, create and share (SSCS) model and the student's mathematical logical thinking skills. In Proceeding of International Conference On Research, Implementation And Education Of Mathematics And Sciences . Yogyakarta: Universitas Negeri Yogyakarta. Retrieved from http://eprints.uny.ac.id/11570/

Linn, R., Bond, L., carr, P., Darling-Hammond, L., Harris, D., Hess, F., \& Shulman, L. (2009). Student learning student achievement: How do teachers measure up? New York: National Board for Professional Teaching Standards. Retrieved from http://www.nbpts.org/sites/default/files/do cuments/research/NBPTS_Student Learning Student Achievement (2).pdf

Muijs, D., \& Reynolds, D. (2005). Effective teaching: Evidence and practice. London: SAGE Publications.

Pazzini, E. L. (1991). SSCS problem solving: Implementation handbook. Iowa: Science Education Department, the University of Iowa.

Pazzini, E. L., Abell, S. K., \& Shepardson, D. S. (1988). Rethinking thingking in the science classroom. In The Science Teacher (pp. 22-25). Retrieved from http://plato.acadiau.ca/courses/educ/GMa cKinnon/Educ4143/graphics/Rethinking thinking.pdf

Rahmatudin, J. (2013). Penerapan model pembelajaran search, solve, create, and share untuk meningkatkan kemampuan penalaran matematis dan self concept siswa SMP Negeri 1 Kedawung. Universitas Pendidikan Indonesia. Retrieved from http://repository.upi.edu/583/ 
Rencher, A. C. (1998). Multivariate statistical inference and applications. New York: Wiley.

Rosnawati, R. (2013). Kemampuan penalaran matematika siswa SMP Indonesia pada TIMSS 2011. In Prosiding Seminar Nasional Penelitian, Pendidikan dan Penerapan MIPA (p. M-6). Yogyakarta: Fakultas MIPA, Universitas Negeri Yogyakarta. Retrieved from http://staffnew.uny.ac.id/upload/1320018 08/penelitian/Makalah+Semnas+2013+an + R+Rosnawati+FMIPA+UNY.pdf

Santrock, J. (2010). Educational Psychology. Handbook of Educational Psychology. http://doi.org/10.1146/annurev.ps.05.0201 54.002041

Schunk, D. H., Pintrich, P. R., \& Meece, J. L. (2008). Motivation in education: Theory, research, and applications. New Jersey: Pearson/Merrill Prentice Hall.

Slavin, R. E. (2014). Educational Psychology Theory and Practice- Pearson Etext Access Card. Pearson College Div.

Stevens, J. P. (2009). Applied multivariate statistics for the social sciences. London: Routledge.

Suryadi, D. (2012). Membangun budaya baru dalam berpikir matematika. Bandung: Rizqi Press.

The National Council of Teachers of Mathematics. (2000). NCTM principles and standards for school mathematics,. Association Drive, Reston, VA: Library of Congres Cataloguing-in-Publication Data. Retrieved from https://www.nctm.org/store/Products/NC TM-Principles-and-Standards-for-SchoolMathematics,-Full-Edition-(PDF)/

Turmudi. (2009). Landasan filsafat dan teori pembelajaran Berparadigma eksploratif dan investigatif. Jakarta : Leuser Cita Pustaka.

Wijayanti, D. (2016). Pengembangan perangkat pembelajaran statistika dan peluang dengan metode penemuan terbimbing berorientasi kurikulum 2013 untuk siswa kelas X. Jurnal Riset Pendidikan Matematika, 3(1), 23. http://doi.org/10.21831/jrpm.v3i1.6449 